\title{
Pixton as a digital teaching tool to encourage the writing skill
}

\author{
Pixton como una herramienta de enseñanza para fomentar la habilidad de \\ escritura
}

Ximena Gabriela Ortiz Orellana. ${ }^{1}$ \& Jazmina Ivonne Mena Mayorga. ${ }^{2}$

\begin{abstract}
.
DOI: https://doi.org/10.33262/cienciadigital.v5i3.1621

Introduction. The use of Information and Communication Technology (ICT) in education has increased due to the technological era we are living nowadays. Teaching English also demands to be informed of the new teaching trends that technology offers. As a result, teachers must be aware of the important role that technology plays in the teaching-learning of English. Objective. To analyze if Pixton, a digital storytelling tool, improves the writing skill on English foreign language learners in higher education. Methodology. The research was carried out in an educational Institution in Ecuador with a target population of forty-eight students who were in an A2 level. A quasi-experimental research was conducted where twenty-four participants were the experimental group and the other twenty-four participants were the control group. A pre-test was practiced for both groups to determine their writing skills. Consequently, students in both groups took a post-test to define if Pixton (the digital storytelling tool) used during classes made any difference on the writing skill performance. Results. The findings indicated that the students who were part of the experimental group had a higher average in the writing
\end{abstract}

\footnotetext{
${ }^{1}$ Pontificia Universidad Católica del Ecuador - Sede Ambato, Maestría en Pedagogía del Inglés como Lengua Extranjera, Tungurahua, ximena.g.ortiz.o@ pucesa.edu.ec, https://orcid.org/0000-0002-53840746

${ }^{2}$ Pontificia Universidad Católica del Ecuador - Sede Ambato, Maestría en Pedagogía del Inglés como Lengua Extranjera, Tungurahua, jazmin_menamayorga@hotmial.com, https://orcid.org/0000-00025073-5967
} 
post-test in comparison with the average of the control group. Therefore, learners from the experimental group outperformed learners in the control group. Conclusion. Due to this fact, the use of Pixton as a digital storytelling tool had enhance the writing skill on A2 level learners in the institute.

Keywords: Technology, Pixton, Storytelling, Writing skills

\section{Resumen.}

Introducción. El uso de las Tecnologías de la Información y la Comunicación (TIC) en la educación ha aumentado debido a la era tecnológica en la que vivimos hoy en día. La enseñanza del inglés también exige estar informado de las nuevas tendencias docentes que ofrece la tecnología. Como resultado, los profesores deben ser conscientes del papel importante que desempeña la tecnología en la enseñanza-aprendizaje del inglés. Objetivo. Analizar si Pixton, una herramienta de narración digital, mejora la habilidad de escritura en los estudiantes de inglés en la educación superior. Metodología. Se llevó a cabo en un Instituto educativo en Ecuador con una población objetivo de cuarenta y ocho estudiantes de un nivel A2. Se realizó una investigación cuasi-experimental donde veinte cuatro participantes fueron el grupo experimental y los otros veinte cuatro fueron el grupo control. Se empleó una prueba previa para ambos grupos para evaluar sus habilidades de escritura. Después de eso, los estudiantes de ambos grupos tomaron una prueba posterior para conocer si Pixton (la narración digital) utilizado durante las clases causó alguna diferencia en el rendimiento de las habilidades de escritura. Resultados. Los resultados indicaron que los estudiantes que formaron parte del grupo experimental tuvieron un promedio más alto en la prueba posterior de escritura en comparación con el promedio del grupo control. Por lo tanto, los estudiantes del grupo experimental superaron a los estudiantes del grupo control. Conclusión. Debido a este hecho, se concluyó que el uso de Pixton como una herramienta digital de narración de cuentos facilita la habilidad de escritura en los estudiantes de nivel A2 en el instituto.

Palabras claves: Tecnología, Pixton, Narración, Habilidades de escritura.

\section{Introduction.}

English language has become an important tool in several fields such as business, associations, sports, and education. It is known that a language involves different skills like reading, listening, speaking and writing. Education First (EF) English Proficiency Index (2020) claims that Ecuador is located as number ninety-three of one hundred countries which study English as a foreign language. Ecuador presents an extremely low proficiency in the English language due to the lack of interest on learning the foreign language as well as the lack of professional development to be informed of the new teaching trends that technology offers. Therefore, teachers must use different methodological alternatives to reach an effective goal in the learning process. Nonetheless, students as English Foreign Learners (EFL) have found some difficulties in acquiring knowledge. Students do not find interest on learning English as they think it is 
not necessary for their lives. In addition, students do not feel motivated and comfortable learning in a traditional way. For this reason, Kee and Samsudin (2014) mention that, ICT turns to be an essential tool within the educational process to provide the teacher and students with the opportunity to be aware and explore all the aspects that deal with their own education (as cited by Nariyati, 2020, par. 1). Consequently, education and technology are facing together a huge impact on students learning process thanks to the new era. Therefore, teachers need to understand and focus on different alternatives that might help them to achieve interactive input by the hand of technology.

According to the Ecuadorian in-service English Teacher Standards - The English Language Learning Standards (2012) given by the Ministry of Education states that:

"Given the fact that Ecuador is a multicultural country, a certain number of Ecuadorian students who are learning English may descend from indigenous cultures - where Spanish is their second language; and English their third- $[\ldots]$ Therefore, Ecuadorian English teachers need to have knowledge of other cultures and know how culture may affect their learning of English in Ecuador.” (p. 2)

It is known that Chimborazo province is a multicultural place since the thirty eight percent of the population belong to an indigenous community (INEC, 2010). Nevertheless, teachers might find difficulties while teaching English to students with different kind of backgrounds. Students need to be part of their learning process by having an interactive and active input that help them learn from each other. Also, teachers who work for public institutions must follow a book given by the Ministry of Education. These books concentrate more on grammar structures making teachers forget about the other skills that are important for the English language. On the other hand, some public Institutes do not have to follow a specific guidebook, making teachers gathering more attention to the grammar point while developing and teaching the English language. According to Mart (2013), getting the knowledge of grammar and vocabulary is considered a significant element when teaching and learning English as a Foreign Language (EFL) so that teachers pay attention to this specific part of the learning process rather than other skills like writing. Teachers are required to reflect on an effective strategy in order to develop and mix different skills in the students' learning process.

Riobamba, the capital of the province has around five institutes where English is taught as part of their curricula (SENESCYT, 2019). Teachers that are considered to be part of the old schools follow a traditional path in which students repeat and learn grammar structures. Another reason that put English teachers against the situation is the lack of time that the Institutes give for the English subject. If students do not have a reasonable number of hours during the week they are not going to have a correct input when learning a new language.

Riobamba Institute is one of the biggest institutes in the city with eleven English teachers and almost two thousand students according to SENESCYT (2019). The lack of interest and practice on the writing skill has led students to have a low interaction with this skill in English. As said by Asrobi and Prasetyaningrum (2017), "Writing is the least popular 
language skill and most students consider writing is the least useful or unnecessary for them to be mastered" (p.1). Teachers and students do not give this skill the importance that it should have. Also, teachers do not include optical evaluations in their teaching lessons, so it turns to be a negative factor in the learning process. This situation has made students depend on the use of dictionaries or translators. Therefore, EFL learners agree to claim that writing is the most difficult skill to be learnt (Jodaie, 2011). EFL students believe that English needs to be translated word by word. This a terrible mistake that has been carried out since students are in high school. For all these reasons, it is necessary for teachers to be informed about the new technology tools to enhance the teaching and learning process of English in the institution.

\section{Theorical Framework}

As days go by the traditional writing such us presentations, creating tables and writing by hand has been forgotten. Therefore, computers and technology are the new tools for this era to learn the writing skill. A necessary aspect to take into consideration when it is time to write, must be the way of how the ideas come together in order to create and develop a well-structured writing. Students will be able to improve this skill by the support of different tools that make them feel comfortable and not to be afraid of making mistakes when writing.

For the last ten years, researchers defined technology as leadership with the aim of making actions that facilitate effectiveness within the use of technology in schools (Anderson \& Dexter, 2000). That is to say, technology has become the key of success in education. Students find it easy to understand and develop their input through the new era they are living in. However, for teachers of different generations in which technology was not the main source to educate, it is hard to comprehend and develop a well-known understanding of this tool (Raman \& Thannimalai, 2019). Nowadays, teachers have inspired themselves to learn through the use of technology that has turned to be a main tool in teaching. For a learner, whose English is their second language, motivation and a correct input is crucial in order to make them realize and be aware of how the language works. Based on the four skills in English, writing seems to be the hardest and stressful skill to learn and acquire. Consequently, technology offers a lot of tools to enhance and help students develop this skill. Different instruments can be found and develop through the interaction of technology. Some of them may be free to all the users and some others may not. In order to provide a useful input on students a variety of instruments might appear to enhance the skills through the use of English. One of these utensils is called Pixton, it is an attractive platform design for students and users to create comic strips online. This tool is considered as an authentic resource for teacher to use in their lessons in order to create and motivate students to practice and evolve their input based on writing skills.

Pixton is a comic improvement website that can be used to improve the learning process to create a positive attitude and increase motivation (Kilickaya \& Krajka, 2012). On the other hand, Pixton is considered as a creative tool due to the fact that engage teachers and students in the world of comics. In addition, students have the opportunity to express, 
create, comment and develop their critical thinking skill (Cabrera et al., 2018). They have the possibility to convey an idea into a real and original context where they tell the story in a logical sequence, collaborating with others and developing language skills in a multimodal setting (Lee, 2013). However, Pixton as a free tool has different aspects to take into consideration, such as the limitation of backgrounds within the slides that a participant may want to use in order to create a comic. Most of them are locked giving with it a low interaction on the platform. However, the teacher and students make the difference making the platform useful and interactive. Students find their way in order to create and illustrate their thoughts and imagination through the tool.

This story telling tool involves a huge amount of imagination where children, teenagers and even adults will have the chance to cooperate within Pixton storytelling tool. Furthermore, quality and advantage in the use of Pixton is that besides practicing the writing skill, it also increases and develops the student's vocabulary and grammar structure of the language. Pixton is also considered as a language art due to the fact that since the language skills are difficult to master, this tool can transform bad experiences with the English language into a great satisfaction on acquiring the language. As said by O'Shea (2011), Pixton is well-known as a secret weapon for teachers. (par. 3). This is why Pixton is an interactive tool in which students are part of an independent learning and the teacher acts as a facilitator of it. Also, students have the opportunity to feel free with their thoughts and to capture them through the use of Pixton.

Pixton can turn a boring learning into a comic and interactive way of learning. Teachers and students learn through the journey of acquiring new knowledge thanks to pixton platform. Students are the ones who feel free to write and develop their own understanding of the language by the guide of the teacher. Also, students are allowed to use their own words or ideas with the purpose of taking away the tension and frustration when developing the writing skill. Pixton has become a well-known strategy and equipment for teachers due to the fact that it can be a path for students to grow and evolve with the use of the language (Joneyd \& Deris, 2019). Consequently, teachers and students will find a new way of acquiring a language which sometimes can cause fear when using something that can be completely new for teaching and studying a second language.

Critical thinking also change when using Pixton. Students are in charge to construct, create and progress their own understanding of the language by illustrating them into a comic and interact tool. In order to demonstrate and improve their understanding indoors this writing storytelling tool also becomes an important and essential instrument to be discovered and analyzed. Based on the four skills of the English language, writing gives the impression to be the most difficult part to learn. Writing as Dahlström (2018) mentions “.... is important because it's used extensively in higher education and in the workplace. If students don't know how to express themselves in writing, they won't be able to communicate well with professors, employers, peers, or just about anyone else" (p. 3). For this reason, writing is also part of this jigsaw of acquiring the language. It has to be taken into account in order to make students be part and transform the way of thinking about writing. 
Once students find a new way of acquiring a language and also making them part of it as a whole, they are interested on learning and interact with a second language. That makes teachers find it easier to have a motivation and input among the learning process. Additionally, the teacher only acts as a guide or facilitator during this process where students find themselves as a true learner of the language. In the English language, the writing skill has been considered as a frustrating skill to learn and develop for many years (Eryaman, 2008). Most of the students are afraid to write because they feel ashamed to give or provide their ideas to people they may not know. In other words, students construct a barrier between them and the reader since they are afraid of knowing that their writing work is not good enough for them. What they do not know is that writing is important in every situation they might be involved; that is to say on writing reports, articles, letters, short messages, among others. For this reason, writing is a narrative skill obtained by a formal education which at the same time is connected with the reading, listening and speaking skill of the English language (Graham \& Perin, 2007). Moreover, composing a writing document is part of putting ideas and thoughts together in order to obtain the result expected (Yıldırım, Demir \& Kutlu, 2020).

Another aspect to take into consideration about writing as Simin and Tavangar (2009) mention is that "Writing is an important communication skill and has an essential role in second language learning process" (as cited by Javadi-Safa, 2018, p. 1). Thus, writing have a positive impact on a student learning process, they have to be aware of the greatest opportunities this brings to their own understanding and development of the English language.

On the other hand, if students are aware of the benefits that writing could bring to their lives, everything might be much easier and they focus on this skill as an opportunity to develop and interact with people all around the globe. Writing in English help students and writers to convert messages or ideas into real communication being this language as their first or second language (Sumarsih \& Sanjaya, 2013). The impact that writing has all over the world is huge. Writers can communicate and interact with each other by the use of this skill in a way of practice and keeping the language developing in a satisfactory way (Brown, 2007). Writing is part of the daily life of a person, it is necessary to have that in mind, so teachers and students interact and create a worth and entertain communication.

There are several reasons to find weaknesses in the writing skill when EFL learners perform a writing task. According to Tan (2011) one of them has to deal with the lack of an effective approach to teach writing, due to the fact that this skill requires the integration of other skills, such as reading or listening. So teachers should pay attention to the importance of how it is necessary for students to develop their own way of thinking based on any topic. Second, it would be the fear that students have when they write a short paragraph giving information about themselves. Teachers need to pay more attention to the process and not only to the product or result while students are learning. Third the unproductive lesson that most students need to carry out when learning this skill. Most of the students might feel frustrated when something is not clear during class, so students 
must not be scared to ask in order to have a better understanding of any topic mentioned in class. Forth, the large amount of writing classes that can cause boredom to students. Having their brains active all the time help them have a positive input. Finally, the disintegration of radios, songs, video games, multimedia, computers, and movies when teaching; in other words instruments with different purpose while teaching must be applied (p. 21). There are many reasons why students do not feel comfortable when learning the writing skill. Due to this fact, new ways of teaching and making the class interactive is by the use of tools provided by technology. Students and teachers are the ones who provide and learn new techniques that make a better interaction when learning a language. Furthermore, teachers must be conscious that everything depends on the right use of tools in which students feel relaxed and motivated acquiring the English language.

\section{Methodology.}

The quantitative approach was applied in order to analyze the results in this study. Thus, a problem was formulated to know and consider the settings of delimitations that can be presented during the study. The data collection was measurable and the results were analyzed over and worked with statistics.

On the other hand, the research handled a descriptive analysis due to the fact that each variable was analyzed through the literature review presented above named as the theorical framework. Additionally, the two variables were identified and presented on a data collection. According to Thompson (2009), a descriptive analysis helps the researcher to measure and compare results based on a given sample. This analysis helps to compare and determine how one sample might vary from a different one with the intention to see effectiveness in the case study. The researcher had a clear and well-known idea of how the two variables worked along the case study and to identify if there is any relation between the two variables. An important and relevant aspect to take into consideration was the quasi-experimental investigation that was headed by this study. Two groups were conducted and both worked in the same rhythm, with the only difference that one was the control group and the other one the experimental group with the help of an intervention plan. At the end of the mediation the results were compared and examined.

The questions on pre-test and post-test used in this inquiry were taken from the PET Cambridge test a scientific reference to ensure the validity and reliability of these tools. The rubric and the questions were modified, reviewed, and approved by the tutor of this investigation.

Forty-eight students were the population of the study. They were students from an A2 level from an institute in Ecuador, classes "F" and "J". Being class " $F$ " the experimental group and class "J" the control group. There were twenty-four participants from class "F" and twenty-four participants from class " J", both of the groups took the pre-test and posttest, and the experimental group experienced Pixton, the storytelling tool, using comics and reactions about it. In order to see how the participants responded to the new tool applied and the effectiveness of it, instruments such as tests (pre and post), writing rubrics 
and creating comics are used. Students were given a pre-test once the case study started. While the process began with both of the groups different materials such as handouts were applied in order to make students use the platform. Pixton platform was used twice a week with the experimental group, but for the control group only handouts and elaborated sheets were given. Students from the experimental group reacted in a positive way due to the fact that they liked the use and interaction of this instrument thanks to the colorful, fun and creative website. At the end of the process the post-test was applied based on different aspects considered in the rubric (used in both tests pre and post) to see the effectiveness of the tool and handouts given.

Based on the importance of the results and taken into consideration that it is a significant aspect during and after the research Hernández, Fernández and Baptista (2016) mentioned that a descriptive statistic aims to describe numbers, results and every single data collected while and during a case study. Consequently, the pre and post-tests helped to see the average of the results while the process of the study was taken. The results will be presented through the use of tables which will help the reader understand and comprehend in a better way how the impact of the digital tool had among the students.

Finally, a quantitative research is taken into consideration due to the fact that it involves a better analysis of the study. Fraenkel, Wallen and Hyun mentions that a "quantitative researcher quantitative data deal primarily with numbers, [...] established widely agreedon general formulations of steps that guide researchers in their work" (p.7). For this reason, a quantitative research have a tendency to be pre-established dealing with characteristics such as the experimental group and control group. The experimental group emphasizes that the group receives a treatment such as a new textbook or a different method of teaching, while the control group receives no treatment or a different treatment (p. 266).

Results.

Table 1. Pre-test control group

\begin{tabular}{ccccccc}
\hline Student & Ideas & Organization & Expression & Conventions & Legibility & Total \\
\hline A & 3 & 2 & 2 & 2 & 3 & 12 \\
B & 3 & 3 & 2 & 3 & 4 & 15 \\
C & 4 & 3 & 3 & 3 & 4 & 17 \\
D & 3 & 3 & 2 & 3 & 3 & 14 \\
E & 3 & 3 & 3 & 3 & 4 & 16 \\
F & 4 & 3 & 3 & 3 & 4 & 17 \\
G & 4 & 4 & 3 & 3 & 4 & 18 \\
H & 3 & 3 & 3 & 4 & 3 & 16 \\
I & 3 & 2 & 3 & 1 & 4 & 13 \\
J & 4 & 3 & 3 & 3 & 4 & 17 \\
K & 4 & 3 & 3 & 3 & 3 & 16 \\
L & 4 & 3 & 3 & 3 & 4 & 17 \\
M & 2 & 2 & 2 & 2 & 3 & 11
\end{tabular}




$\begin{array}{ccccccc}\mathrm{N} & 3 & 3 & 3 & 2 & 4 & 15 \\ \mathrm{O} & 2 & 3 & 3 & 2 & 4 & 14 \\ \mathrm{P} & 3 & 3 & 3 & 3 & 4 & 16 \\ \mathrm{Q} & 2 & 1 & 1 & 2 & 3 & 9 \\ \mathrm{R} & 3 & 3 & 2 & 2 & 3 & 13 \\ \mathrm{~S} & 2 & 2 & 1 & 2 & 3 & 10 \\ \mathrm{~T} & 4 & 3 & 4 & 3 & 4 & 18 \\ \mathrm{U} & 2 & 2 & 2 & 2 & 2 & 10 \\ \mathrm{~V} & 4 & 4 & 4 & 3 & 4 & 19 \\ \mathrm{~W} & 3 & 3 & 2 & 2 & 2 & 12 \\ \mathrm{X} & 3 & 2 & 1 & 1 & 3 & 10 \\ \mathrm{X} & 3,13 & 2,75 & 2,54 & 2,50 & 3,46 & 14,38\end{array}$

Note: The media of the control group concerning the pre-test is 14, 38 over 20.

Source: Pre-test control group

Developed by: The author

Table 2. Pre-test experimental group

\begin{tabular}{ccccccc}
\hline Student & Ideas & Organization & Expression & Conventions & Legibility & Total \\
\hline A & 3 & 2 & 3 & 3 & 4 & 15 \\
B & 3 & 2 & 2 & 3 & 4 & 14 \\
C & 2 & 3 & 3 & 2 & 4 & 14 \\
D & 3 & 3 & 1 & 3 & 3 & 13 \\
E & 3 & 2 & 3 & 3 & 4 & 15 \\
F & 3 & 1 & 3 & 3 & 3 & 13 \\
G & 3 & 3 & 1 & 3 & 3 & 13 \\
H & 2 & 3 & 2 & 4 & 3 & 14 \\
I & 3 & 2 & 3 & 1 & 4 & 13 \\
J & 4 & 3 & 3 & 3 & 4 & 17 \\
K & 4 & 4 & 3 & 1 & 3 & 15 \\
L & 4 & 4 & 4 & 2 & 4 & 18 \\
M & 3 & 2 & 3 & 3 & 4 & 15 \\
N & 3 & 3 & 1 & 2 & 4 & 13 \\
O & 3 & 3 & 2 & 2 & 4 & 14 \\
P & 3 & 4 & 3 & 3 & 4 & 17 \\
Q & 3 & 3 & 3 & 3 & 4 & 16 \\
R & 4 & 4 & 3 & 1 & 4 & 16 \\
S & 2 & 3 & 2 & 3 & 4 & 14 \\
T & 3 & 4 & 4 & 4 & 4 & 19 \\
U & 2 & 1 & 1 & 1 & 4 & 9 \\
V & 4 & 3 & 2 & 3 & 4 & 16 \\
W & 3 & 4 & 2 & 4 & 4 & 17 \\
X & 4 & 4 & 3 & 3 & 4 & 18 \\
X & 3,08 & 2,92 & 2,50 & 2,63 & 3,79 & 14,92 \\
\hline
\end{tabular}

Note: The media of the experimental group concerning the pre-test is 14, 92 over 20.

Source: Pre-test experimental group

Developed by: The author 
Table 3. Post-test control group

\begin{tabular}{ccccccc}
\hline Student & Ideas & Organization & Expression & Conventions & Legibility & Total \\
\hline A & 4 & 4 & 3 & 3 & 3 & 17 \\
B & 3 & 3 & 2 & 3 & 4 & 15 \\
C & 4 & 3 & 4 & 3 & 4 & 18 \\
D & 3 & 3 & 2 & 2 & 3 & 13 \\
E & 4 & 3 & 3 & 3 & 4 & 17 \\
F & 4 & 3 & 3 & 3 & 4 & 17 \\
G & 4 & 4 & 3 & 4 & 4 & 19 \\
H & 2 & 2 & 2 & 3 & 3 & 12 \\
I & 3 & 3 & 3 & 3 & 4 & 16 \\
J & 4 & 3 & 3 & 3 & 4 & 17 \\
K & 4 & 3 & 3 & 4 & 4 & 18 \\
L & 4 & 4 & 3 & 3 & 4 & 18 \\
M & 3 & 3 & 3 & 3 & 4 & 16 \\
N & 4 & 4 & 3 & 3 & 4 & 18 \\
O & 4 & 4 & 3 & 4 & 4 & 19 \\
P & 4 & 3 & 3 & 4 & 4 & 18 \\
Q & 3 & 3 & 3 & 3 & 4 & 16 \\
R & 4 & 3 & 4 & 4 & 4 & 19 \\
S & 2 & 1 & 1 & 2 & 2 & 8 \\
T & 4 & 4 & 4 & 3 & 4 & 19 \\
U & 4 & 3 & 3 & 4 & 4 & 18 \\
V & 4 & 3 & 4 & 3 & 3 & 17 \\
W & 4 & 4 & 3 & 4 & 4 & 19 \\
X & 3 & 3 & 2 & 3 & 3 & 14 \\
X & 3,58 & 3,17 & 2,92 & 3,21 & 3,71 & 16,58 \\
\hline
\end{tabular}

Note: The media of the control group concerning the post-test is 16, 58 over 20.

Source: Post-test control group

Developed by: The author

Table 4. Post-test experimental group

\begin{tabular}{ccccccc}
\hline Student & Ideas & Organization & Expression & Conventions & Legibility & Total \\
\hline A & 4 & 4 & 3 & 4 & 4 & 19 \\
B & 4 & 3 & 3 & 3 & 4 & 17 \\
C & 4 & 4 & 3 & 4 & 4 & 19 \\
D & 4 & 4 & 3 & 4 & 4 & 19 \\
E & 4 & 3 & 4 & 4 & 4 & 19 \\
F & 4 & 3 & 3 & 3 & 4 & 17 \\
G & 3 & 4 & 3 & 3 & 4 & 17 \\
H & 3 & 3 & 3 & 4 & 4 & 17 \\
I & 4 & 4 & 4 & 4 & 4 & 20 \\
J & 4 & 4 & 3 & 4 & 4 & 19
\end{tabular}


K

$\mathrm{L}$

M

$\mathrm{N}$

O$$
P
$$

Q

$\mathrm{R}$

$\mathrm{S}$

$\mathrm{T}$

U

$\mathrm{V}$

W

$\mathrm{X}$

又

\section{4}

$$
4
$$

4

4

4

4

4

3

4

3

4

3

4

4

4

3,79
4

4

4

3

4

4

4

4

3

4

3

4

4

3,67

3

4

3

3

3

3

4

4

4

4

4

4

3

4

3

4

3,42

Note: The media of the experimental group concerning the post-test is 18, 33 over 20.

Source: Post-test experimental group

Developed by: The author

The writings exposed by the students of the control group were analyzed thanks to the handouts and activities given in class in order to see the effectiveness of their work shown in Table 5.

Table 5. Control Group - Results

\begin{tabular}{lccc}
\hline \multicolumn{1}{c}{ Denomination } & Value & $\%$ & Observation \\
\hline Variance & 0,4884 & $48,85 \%$ & \\
Standard deviation & 0,6989 & $69,89 \%$ & \\
Variance coefficient & 0,2329 & $23,30 \%$ & \\
Correlation coefficient - Results & 0,3680 & $\mathbf{3 6 , 8 1 \%}$ & Between pre and post-test \\
Correlation coefficient - Medians & 0,9232 & $92,32 \%$ & Between the medians \\
Correlation coefficient - Global & 0,1877 & $18,78 \%$ & Between the post-tests \\
\hline
\end{tabular}

Note: The correlation coefficient of the control group between the pre and post-test is $36,81 \%$ over 100. Source: Writing rubrics

Developed by: The author

Evidently, the average between the pre and post-test show a low percent of performance among students who did not use Pixton as a main tool to interact in class. As a result, the students have a little progress on their writing skill.

On the other hand, the writings given by the students of the experimental group show a huge difference thanks to the use of Pixton's platform as how it is shown in Table 6. 
Table 6. Experimental Group - Results

\begin{tabular}{lccc}
\hline \multicolumn{1}{c}{ Denomination } & Value & $\%$ & Observation \\
\hline Variance & 0,2408 & $24,09 \%$ & \\
Standard deviation & 0,4908 & $49,08 \%$ & \\
Variance coefficient & 0,1227 & $12,27 \%$ & \\
Correlation coefficient - Results & 0,7443 & $74,43 \%$ & Between pre and post-test \\
Correlation coefficient - Medians & 0,9506 & $95,07 \%$ & Between the medians \\
Correlation coefficient - Global & 0,1877 & $18,78 \%$ & Between the post-tests \\
\hline
\end{tabular}

Note: The correlation coefficient of the experimental group between the pre and post-test is $74,43 \%$ over 100.

Source: Writing rubrics

Developed by: The author

Visibly, the average between the pre and post-test show a higher percent of performance between the students who used Pixton as a way to practice their writing skill. This tool have given the change to indicate a huge difference concerning the control group.

Table 7. Average comparison between the tests

\begin{tabular}{ll}
\hline Average results & \\
\hline Pre-test (control group) & 14,38 \\
Pre-test (experimental group) & 14,92 \\
Post- test (control group) & 16,58 \\
Post- test experimental group) & 18,33 \\
\hline Source: Writing rubrics & \\
Developed by: The author
\end{tabular}

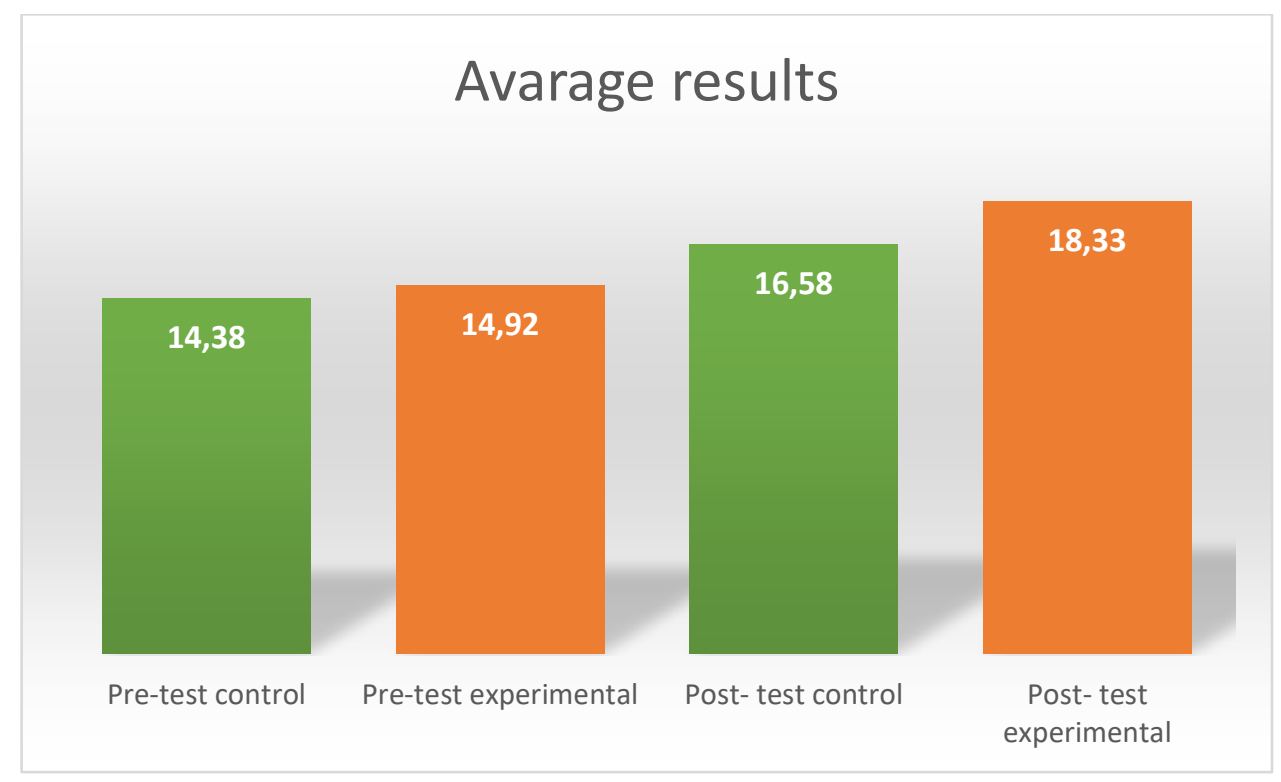

Figure 1. Comparison before and after the tests taken in both groups Developed by: The author

Once all the results were analyzed from the pre and post-tests, an average results were taken into consideration in order to observe how students were able to accomplish the 
writing skills throughout different strategies were used among the study. For instance, the pre-test taken by group "F" and "J" showed a similarity level of knowledge in the English language based on the writing skill.

During and after applying Pixton as digital tool students from both of the groups got a higher average on their results. But the experimental group was the one who had a better enhance of the writing skill through the use of Pixton. Therefore, Pixton improve students' writing skills.

\section{Conclusions.}

- Students do not feel pressure at the moment of acquiring the language due to the fact that they feel free and comfortable by using the Pixton platform. Since the platform is eye-catching for users, students feel relaxed creating stories. Also, teachers' have the opportunity to implement a collaborative work among students.

- Pixton as a digital storytelling tool can be effective as teaching in a traditional way thanks to the globalization and the net. Most children, teenagers and even adults have the ability to develop, focus and practice in a modern society in which education can be the first to follow in order to acquire a second language using digital tools.

- Being in a well-organized atmosphere gives teachers the chance to have a positive input among students with the aim to persuade their learning process through the use of Pixton as a digital tool.

\section{References.}

Anderson, R., \& Dexter, S. (2000). School Technology Leadership: Incidence and Impact. UC Irvine: Center for Research on Information Technology and Organizations. https://bit.ly/3p4fYZQ

Asrobi, M., \& Prasetyaningrum, A. (2017). Trait Based Assessment on Teaching Writing Skill for EFL Learners. Canadian Center of Science and Education, 10(11), 199203. doi: 10.5539/elt.v10n11p199

Brown, D. (2007). Teaching by Principles: An Interactive Approach to Language Pedagogy (3rd ed.). New York, United States: Pearson Education.

Cabrera, P. et al. (2018). The Impact of Using Pixton for Teaching Grammar and Vocabulary in the EFL Ecuadorian Context. The Journal of Teaching English with Technology, 18(1), 53-76. http://www.tewtjournal.org 
Dahlström, H. (2018). Digital writing tools from the student perspective. Access, affordances, and agency. Education and Information Technologies, 24(n.n.), 1563-1581. https://doi.org/10.1007/s10639-018-9844-x

Education First. (2020). EF English Proficiency. EF English Proficiency Index (EF EPI). https://www.ef.com.ec/epi/

Eryaman, M. (2008). Writing, Method and Hermeneutics: Towards an Existential Pedagogy. Elementary Education Online, 7(1), 2-14. http://ilkogretimonline.org.tr

Fraenkel, J., Wallen, N., \& Hyun, H. (2012). How to Design and Evaluate Research in Education. New York, United States: McGrawHill.

Graham, S., \& Perin, D. (2007). A Meta-Analysis of Writing Instruction for Adolescent Students. Journal of Educational Psychology, 99(3), 445-476. doi: 10.1037/00220663.99.3.445

Hernández, R., Fernández, C., \& Baptista, P. (2016). Research Methodology. México: McGraw Hill Education.

Javadi-Safa, A. (2018). A Brief Overview of Key Issues in Second Language Writing Teaching and Research. International Journal of Education \& Literacy Studies, 6(2), 15-25. http://dx.doi.org/10.7575/aiac.ijels.v.6n.2p.15

Jodaie, M. (2011). A Comparative Study of EFL Teachers' and Intermediate High School Students' Perceptions of Written Corrective Feedback on Grammatical Errors. English Language Teaching, 4(4), 356-48. doi:10.5539/elt.v4n4p36

Joneyd, N., \& Deris, F. (2019). Using Student-Generated Web Comics on Pixton as a Tool for Learning Shakespearean Drama. International Journal of Recent Technology and Engineering, 8(n.n.), 800-803. doi:10.35940/ijrte.B1166.0982S919

Kee, C., \& Samsudin, Z. (2014). Mobile Devices: Toys or Learning Tools for the 21st Century Teenagers. The Turkish Online Journal of Educational Technology, 13(3), 107-122. https://bit.ly/3p8YtHV

Kilickaya, F., \& Krajka, J. (2012). Can the Use ff Web-Based Comic Strip Creation Tool Facilitate EFL Learners' Grammar and Sentence Writing? British Journal of Educational Technology, 43(6), 161-165. doi:10.1111/j.1467-8535.2012.01298.x

Lee, V. (2013). Using Pixton as a Tool in the Classroom. ETEC 510. https://bit.ly/37DN7EH 
Mart, Ç. (2013). Teaching Grammar in Context: Why and How? Theory and Practice in Language Studies, 3(1), 124-129. doi:10.4304/tpls.3.1.124-129

Ministry of Education. (2012). Ecuadorian in-service English Teacher Standards-The English Language Learning Standards. https://bit.ly/2WAJ3Qm

Ministry of Higher Education, Science, Technology and Innovation-SENESCYT. (2019). Academic Offer of Higher Education Institutions. https://bit.ly/2J5o6Ke

Nariyati, N., Sudirman, D., \& Pratiwi, N. (2020). EFL Pre-Service Teachers' Perception Toward the use of Mobile Assisted Language Learning in Teaching English. International Journal of language Education, 4(1), 38-47. doi: 10.26858/ijole.v4i2.10052

National Institute of Statistics and Census-INEC. (2010). Provincial Fascicle Chimborazo. https://bit.ly/3rq1e9Q

O'Shea, K. (2011). Pixton. Atlassian Confluence. https://bit.ly/2WANdaW

Raman, A., \& Thannimalai, R. (2019). Importance of Technology Leadership for Technology Integration: Gender and Professional Development Perspective. SAGE Open, 1-13. doi: 10.1177/2158244019893707

Simin, S., \& Tavangar, M. (2009). Metadiscourse Knowledge and Use in Iranian EFL Writing. The Asian EFL Journal, 11(1), 230-255. https://bit.ly/2KMw8bi

Sumarsih, M., \& Sanjaya, D. (2013). TPS as an Effective Technique to Enhance the Students' Achievement on Writing Descriptive Text. English Language Teaching, 6(12), 106-113. doi: 10.5539/elt.v6n12p106

Tan, B. (2011). Innovating Writing Centers and Online Writing Labs outside North America. Asian EFL Journal, 13(2), 391-418. https://bit.ly/2KLgahD

Thompson, C. (2009). Descriptive Data Analysis. Air Medical Journal, 28(2), 56-59. doi: 10.1016/j.amj.2008.12.001

Yıldırım, O., Bilican, S., \& Kutlu, O. (2020). Testing the Bidirectional Relationship between Reading and Writing Skills. International Journal of Progressive Education, 16 (3), 253-269. doi: https://doi.org/10.29329/ijpe.2020.248.19

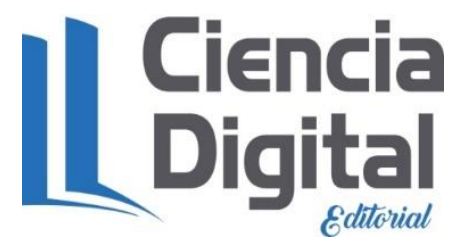




\section{PARA CITAR EL ARTÍCULO INDEXADO.}

Ortiz Orellana , X. G., \& Mena Mayorga , J. I. (2021). Pixton as a digital teaching tool to encourage the writing skill. Ciencia Digital, 5(3), 20-35. https://doi.org/10.33262/cienciadigital.v5i3.1621

\section{¿Ciencia}

El artículo que se publica es de exclusiva responsabilidad de los autores y no necesariamente reflejan el pensamiento de la Revista Ciencia Digital.

El artículo queda en propiedad de la revista y, por tanto, su publicación parcial y/o total en otro medio tiene que ser autorizado por el director de la Revista Ciencia Digital.
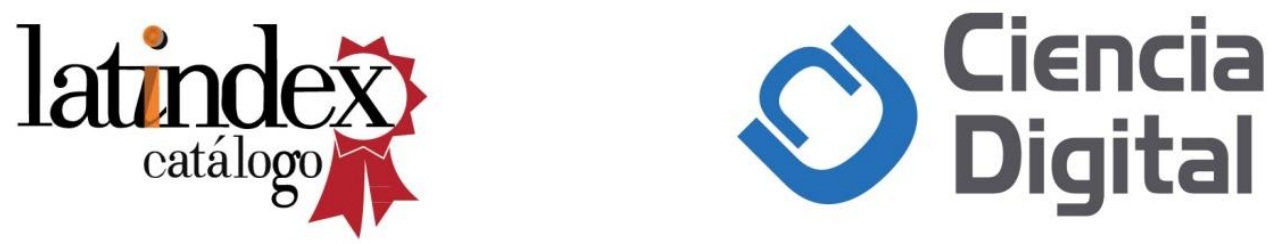